\title{
Atmosphere of Online Retailing Quality Dimensions and Development of Young Generation Customers Loyalty-An Empirical Study of China
}

\author{
Muhammad Ziaullah*, Yi Feng, Shumaila Naz Akhter, Saleem Ahmad \\ School of Management and Economics \\ University of Electronic Science and Technology of China \\ Qingshuihe Campus: No. 2006, Xiyuan Ave, West Hi-Tech Zone, 611731 \\ Chengdu, Sichuan, P.R.China \\ *Corresponding Author: ziacadgk@gmail.com
}

\begin{abstract}
This paper develops a theoretical framework to examine the relationship between e-tail quality dimensions, customer satisfaction and loyalty. Data from a survey of 415 online consumers were used to test the research model. Exploratory Factor Analysis (EFA) and Confirmatory Factor Analysis (CFA) were conducted to demonstrate the reliability and validity of the measurement model, and the Structural Equation Modeling (SEM) technique was used to test the research model. Our results support the proposed hypotheses. The analytical results showed that the system quality, information quality and service quality affect customer satisfaction and loyalty. Information quality aspects have a positive relationship with system quality and service quality dimensions. Moreover, the latter in turn are significantly related to e-loyalty. While no other study has looked at these sorts of data, collected from university students of China. Moreover, the results of this study provide a valuable reference for managers, researchers of online retailing. This study suggests that to enhance customer loyalty, online retailers can devote valuable resources to better establish e-tail quality dimensions, which can develop and improve customer satisfaction in the context of online retailing.
\end{abstract}

Keywords: online retailing, e-satisfaction, e-loyalty, e-tailing dimensions, China

\section{Introduction}

In mainland China, the e-commerce has been developing rapidly, and has great potential for further development. It has been reported that the number of Chinese internet users had reached 618 million and an internet penetration rate was $45.5 \%$ at the end of 2013 [1]. China e-commerce market pegged at $\$ 295$ billion in 2013 and it is projected to be $\$ 713$ billion in 2017 [2,88]. Moreover, in China e-commerce gross merchandise value (GMV) of SME B2B had made up 51.7\%, followed by corporation B2B 26.2\%, online shopping $18.6 \%$, online travel $2.3 \%$ and $\mathrm{O} 2 \mathrm{O}$ at $1.2 \%$ during 2013 [3].

Goodman report [4] indicated that the online customers' population is growing worldwide at a remarkable rate, i.e. $15-20 \%$ per annum. However, this growth rate is highly exponential in mainland China and at $75 \%$ a year. There are 150 million internet users in China who is spending around US\$ $150-250$ per annum. The online retailing market worth is going to be US\$ 305 billion in 2015 .

E-tailing is becoming popular in China. The electronic platforms of Dangdang.com (B2C), Taobao market place (C2C), Tmall.com (B2C), JD.com (B2C) and Amazon.cn (B2C) are the famous e-tailors in China. Moreover, a survey stated that only $3.5 \%$ online customers are completely satisfied with the online shopping process in China [5]. It is also observed that in the China online shopping dramatically increases in recent years, but 
complaints in this regard also keep rising and it is accounted that 410 million cases of ecommerce across the country in the first half of 2013 from which $45.4 \%$ complaints were related with online shopping [3].

Previous studies identified responsiveness, web design, fulfillment or reliability, ease of use, e-scape, customization, e-service quality as major factors that predicts online customers' satisfaction in different contexts [6, 7, 8]. While, Cyr [9] found that characteristics of culture and design, i.e. navigation design, information design and visual design are the antecedents of e-satisfaction in Canada, Germany and China. E-satisfaction is found to play a pivotal role in the establishment of e-loyalty. However, despite the proven importance of e-satisfaction in e-loyalty, the study of their antecedents has only been partially understood in the development of e-loyalty. Our study strengthens the literature by adding different components of e-tail online quality dimensions as possible antecedents in the model of e-loyalty.

Moreover, we characterize e-tail online quality dimensions based on the technological focused approach by seeing a website as an information system by considering system quality and information quality. Similarly a service focused approach sees a website as a service provider and it includes service quality. As an evident from above discussion customers' satisfaction is the central phenomenon in the Chinese e-tailing. We argue that e-tail online quality dimensions are essentials for customers' satisfaction. Therefore, in this research the relative importance of e-tail online quality dimensions are examined to determine their effects on online customers' satisfaction and loyalty.

This study aims to identify the main influence of e-tail quality dimensions on customer satisfaction and loyalty. Understanding the determinants of customer satisfaction and eloyalty is important for both marketing researchers and managers of online retailing. Yet, few studies have examined the different dimensions in predicting customer satisfaction and loyalty for online retailing $[7,10]$. Nevertheless, this kind of study has been conducted before in online retailing.

Hence, contribution of this paper is to address the following research objectives:

- To examine the direct effect of e-tail quality dimensions on customer satisfaction

- To capture customer satisfaction and loyalty in the Chinese e-tailing.

- To develop a structural equation model based on e-tail online quality dimensions theoretical framework for Chinese e-tailers.

- To advise how to improve the e-tail quality dimensions that drives customer satisfaction and loyalty for Chinese e-tailers.

The remainder of this paper is organized as follows. First, a brief literature review of the relationship between e-tail online quality dimensions, e-satisfaction and e-loyalty, and a set of six hypotheses related to the conceptual model are presented. Second, the research methodology is described. Third, Analysis and empirical results are stated. Fourth, the discussion of results and their implications for managers. Finally, conclusions, limitations and future research directions are presented.

\section{Literature Review and Research Hypotheses}

This study draws from previous theories to develop hypotheses and gives better agreement regarding the impact of e-tail quality dimensions of e-satisfaction and e-loyalty. We derive a conceptual model in (Fig.1), which illustrates the hypothesized relationships discussed in the consequent sections. 


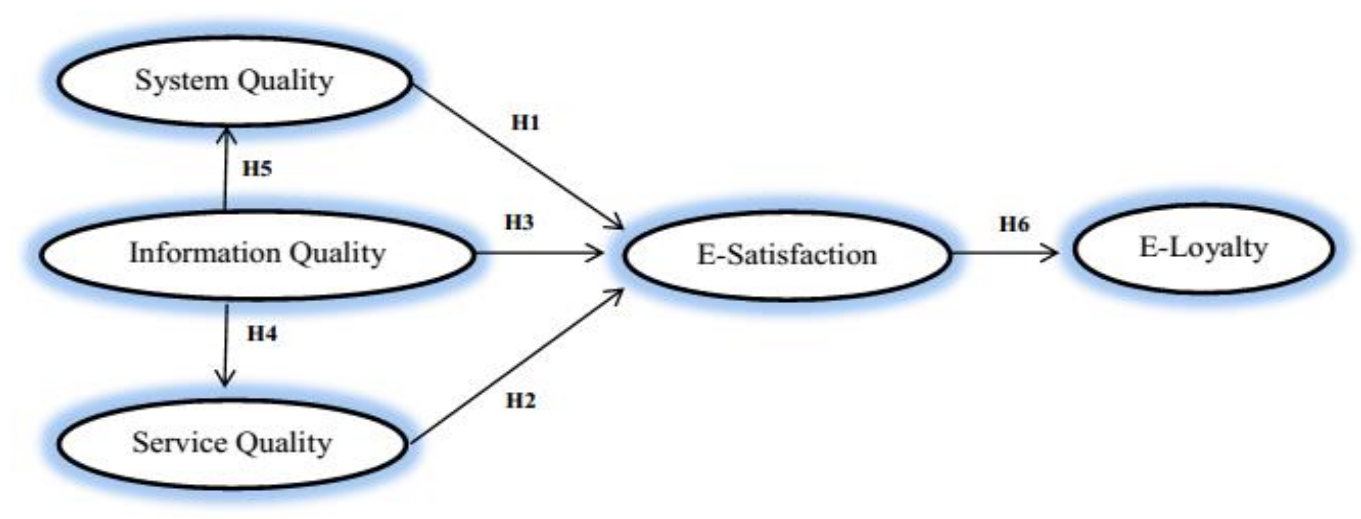

Figure 1. Theoretical Framework and Hypotheses

\subsection{The Importance of Loyalty in Online Retailing}

The customer loyalty has become an important issue for organizations due to tremendous products, services and solutions, existence on a single click away for consumers in the market space.

E-Loyalty refers as customers' favorables attitude and commitment towards online business and implore in repeat purchase behavior [11]. E-loyalty is important because eloyal customers purchase more as compared to the newly acquired customers, in this manner their serving operating cost is low [12].

The loyalty plays an important role in online retailing. Previously, researchers have been highlighted its importance in e-tailing $[10,13]$. It is confirmed that customer loyalty has significant impact on the firm's performance and most of the companies consider the loyalty as an attractive and powerful source of competitive advantage $[11,14,15]$. Loyalty has much contribution in increasing the revenue, decreasing customer acquisition costs, reduction in repeat purchaser's cost of serving and enhancing firm profitability $[16,17]$.

Particularly, it has prominent value in the online environment [18]. According to a rule of thumb, customer acquisition cost is five times greater than customer retention [19]. Loyal customers are willing to pay more premiums [16] and contributed to acquiring new customers through positive referrals, which are consequences to increased revenue [20]. Hence, it is investigated that the cost of developing online loyalty is larger relative to the traditional brick and mortar retailers. Similarly, it accelerates the faster rate of profit growth as relationship which has been developed with customers [21]. E-commerce has created importance of developing a base of loyal customer to online retailers. E-loyalty is useful to create a stable customer base for firms' products and services [22]. Initially online retailers concentrated on generation of large enough customer base, and consequently put in intensive efforts to accomplish profitability based on each loyal customer's lifetime revenue potential [23].

\subsection{Online Retailing Quality Dimensions}

\subsubsection{System Quality}

Ahn et al. [24] refers that system quality describe the measure of Web sites as an information processing system and taps the engineering oriented performance characteristics, i.e. operational efficiency and appearance. Moreover, traditional information system (IS) used various measurements in this area, like system flexibility, 
responsiveness, reliability and system availability [25, 26]. Many of the researchers discussed about some other important aspects of system quality such as design [27, 28], technical adequacy and appearance [29,30,31], security, privacy [28, 30, 31], download delay $[32,33]$, navigation $[30,31,32]$ and hypermedia presentation [33]. System quality has some valuable characteristics such as website design, ease of use, reliability and convenience access $[34,35]$. Moreover, it anticipates the needs of customers which have been identified during system analysis and development phase. Sytem quality is the critical factor for customer satisfaction in the context of online shopping. It is proved that high system quality provides customers more convenience, faster response and privacy [30]. These sorts of system characteristics and capabilities have more influence on perceived ease of use and useful in e-tailers websites [36,37].

The system design quality is an important factor which influence on online customers [38], Anderson and Bezuidenhoudt [39] pointed out that system reliability has a key role in the success of e-commerce. It is found that system quality play an important role and effects on customer satisfaction with internet shopping [40]. Bharati and Chaudhury [34] argued that system quality is positively and directly correlated with the customer's esatisfaction, as increase in system quality of online retailer has enhanced customer's decision making satisfaction. Lin [41] found that system quality is the main determinant of customer satisfaction in internet shopping. On the basis of aforementioned we propose subsequent hypothesis.

\section{H1. There is a positive relationship between system quality and e-satisfaction in young generation customers of Chinese e-tailing.}

\subsubsection{Service Quality}

Service quality refers as availability of communication mechanisms for accepting consumer complaints and their timely resolution with responsiveness, assurance and follow up services [30,31,42]. Moreover, it is the customer evaluations and judgments about the quality of online service delivery [43] and Zeithaml et al. [44] describe e-service quality as the extent to which a website facilitates efficient and effective shopping, purchasing and product delivery. In addition, Bhattacherjee [42] suggested to provide the assistance to consumers for joint problem solving and demonstrating the way of using the complementary products.

In fact, in online shopping there is no any face to face communication between customers and retailers. Thus to create the interaction between customers and retailers, it is necessary for online retailers provide mechanisms of online services in finding, ordering and delivering products to online customers [24]. The service quality depends upon some important and fundamental characteristics such as reliability, responsiveness, tangibles, empathy and assurance $[31,45]$. While service quality characteristics are the paramount for the success or failure of the e-commerce [46].

Cronin and Taylor [47] argued that service quality is the determinant of customer satisfaction, thus customer satisfaction has a strong influence on purchasing intentions. Anderson et al. [48] found that service quality has positive impact on customer satisfaction and consequently on firm's profitability. Rust and Zahorik [49] examined that service quality improvement leads to significant improvement in perceived quality which turns in an increase in customer satisfaction. Service quality is the critical factor for the success of a website and it is the antecedent of customer satisfaction in online shopping [41]. Service quality has a significant relationship to customer satisfaction [50]. Therefore, we propose a subsequent hypothesis on the basis of prior studies. 


\section{H2. There is a positive relationship between service quality and e-satisfaction in young generation customers of Chinese e-tailing.}

\subsubsection{Information Quality}

Information type, variety and detail are the basic requirements of the customers in online shopping decision; these fundamental requirements are usually designed during the web development phase [30].

In the online retailing scenario information comprises of reports and user presentations [24]. The most common characteristics of information quality are currency, accuracy, completeness, understandability and timeliness [36, 51]. Most specified is information quality which is helpful for online customers to make an alternative comparison, better choice selection and overall online shopping decision making. Moreover, researchers also stressed the importance of certain information quality measures such as content and content quality in the context of online shopping [32, 45,]. Actually, characteristics of these measures enhance the intrinsic and extrinsic belief of e-customers towards online shopping $[52,53]$.

It is indicated that online customers sufficiently deliver their personal information to online retailers $[54,55]$. It is proved that information quality plays an important role in customer satisfaction with internet shopping [40,56]. Bharati and Chaudhury [34] argued that information quality is positively and directly correlated with the customer's esatisfaction. Lin [41] argued that information quality is the most important factor in the context of e-satisfaction of online customers. Therefore, we propose subsequent hypotheses.

H3. There is a positive relationship between information quality and e-satisfaction in young generation customers of Chinese e-tailing.

H4: There is a positive relationship between Information quality and service quality in young generation customers of Chinese e-tailing.

H5: There is a positive relationship between Information quality and system quality in young generation customers of Chinese e-tailing.

\subsubsection{The Relationship between e-satisfaction and e-loyalty}

Oliver [22] defined satisfaction as "the summary, psychological state resulting when the emotion surrounding disconfirmed expectations is coupled with a consumer's prior feelings about the consumer experience". Anderson and Srinivasan [57] examined the impact of customer satisfaction on loyalty in the context of e-commerce and defined esatisfaction "as the contentment of the customer with respect to his or her prior purchasing experience with a given electronic commerce firm". Customer satisfaction is an important, and plays a central role in the context of online shopping relationship programs of the firms [58].

Substantially, satisfied customers have more intentions to consume higher services [59], possess more repurchase intentions, and are enthusiastic to recommend the products or services to their acquaintances as compared to those who are not satisfied [60]. However, dissatisfied customer can switch to another retailer, intend to search alternative information and show more resistance to building a close relationship with the retailer [60]. The characteristics of e-tailer satisfaction is the site designing, convenience, and financial security [61], while traditional retailer satisfaction as separated from production satisfaction, it includes satisfaction with individual sales people [61] and store image [62]. Berry [63] argued that an organization's success is dependent on its potential and ability to retain customers especially in a highly competitive market. It is strongly suggested that esatisfaction be the most influential predictor of e-loyalty [64]. E-satisfaction has been found as antecedent of e-loyalty $[44,65]$ and intention to recommend [66]. 
Many of the researchers $[67,68]$ studied the positive significant relationship between esatisfaction and e-loyalty. To verify the relationship between e-satisfaction and e-loyalty, we propose a subsequent hypothesis in the context of the student's segment of e-tailing in China.

H6: There is a positive relationship between e-satisfaction and e-loyalty in young generation customers of Chinese e-tailing.

\section{Research Methodology}

\subsection{Questionnaire Design}

We investigated the literature to identify the valid measures for related constructs and adapted existing scales for the measurement of e-tail online quality dimensions, i.e. system, information and service quality [24], e-satisfaction [7, 69] and e-loyalty [11, 60]. Since the drawn scales from the literature were in English, therefore initial questionnaire was developed in English. In order to achieve the appropriate measurements; The English version questionnaire translated into Chinese by two Chinese, Master and the Ph. D students. Then, the Chinese version questionnaire was translated back into English by another two Chinese, Master and the Ph. D students. The translated English version compared to the original English version for rectifications and to remove discrepancies. The purpose of this common practice of consulting bilingual domain experts is to ensure the meanings consistency, improve understanding of the survey and proper use of terminology in Chinese. In the questionnaire all the indicators were measured using a 7Point-Likert scale ranging from strongly disagree to strongly agree (1=strongly disagree; $7=$ strongly agree).

\subsection{Sampling and Data Collection}

According to Fung Business Intelligence Center, the Chinese online customers are young people and over $60 \%$ were aged 30 or below. The middle aged consumers are seen starting to shop online. Particularly, this group of consumers usually has greater purchasing potential and is willing to pay for high price products via online. It is the noticeable fact that in 2012 just $19.5 \%$ consumers had been aged over 40 years [70]. Hence, university students are likely to be the first consumer segment to adopt ecommerce because of their higher education level and income potential [71]. In addition, while collecting data from university students provides homogeneous background which decreased the bias causing sample equivalence in terms of educational experience, organizational position, cultural difference, etc. [72]. Moreover, university students are skilful in operating computers [73]. Therefore, data for this study was collected from university students of China.

We used a random sampling technique and data was collected from convenient locations of universities like libraries, research labs, campus canteens and mini markets. The survey provides the respondents an incentive for completing and returning questionnaires. Therefore, five hundred fifty questionnaires were distributed initially, a total of 480 questionnaires was returned. Out of the 480 collected, 65 questionnaires were either incomplete or answers were found to be unreliable. Subsequent data analyses were conducted on the 415 usable questionnaires. The response rate was $75.45 \%$. The profile of the useable respondents and their characteristics are listed in Table 1. 
Table 1. Respondent Profile $(n=415)$

\begin{tabular}{llrr}
\hline Demographics Variable & Category & Sample & \\
& Ratio & & \\
\cline { 2 - 4 } Gender & Male & 226 & $54.5 \%$ \\
Age (Years) & Female & 189 & $45.5 \%$ \\
& Below-20 & 83 & $20.0 \%$ \\
Education Level & $20-29$ & 327 & $78.0 \%$ \\
& $30-39$ & 5 & $1.2 \%$ \\
& High School & 3 & $0.7 \%$ \\
& Diploma & 1 & $0.2 \%$ \\
& Bachelor & 244 & $58.8 \%$ \\
& Master & 152 & $36.6 \%$ \\
Shopping Experience & Ph. D & 15 & $3.6 \%$ \\
(Years) & Under-1 & 52 & \\
& & & $12.5 \%$ \\
& $1-4$ & 264 & $63.6 \%$ \\
& Over-4 & 99 & $23.9 \%$ \\
\hline
\end{tabular}

\subsection{Construct Development}

We used Kaiser-Meyer-Olkin (KMO) to measure sampling adequacy and the Bartlett test of sphericity. The output shows KMO value of 0.952 with the significance of Bartlett's test at 0.000 level, and also indicates the data for exploratory factor analysis (EFA) fitting. We used maximum likelihood analysis for data reduction and promax rotation with Kaiser Normalizations for clarifying the factors. Hence EFA was conducted by specifying five numbers of factors. The cumulative variance explanation reaches $69.09 \%$. All the items have loadings $>0.30$ on the construct in the pattern matrix. Hair et al. [74] supported this value. The results of EFA are shown in Table 2.

Table 2. Results of Exploratory Factor Analysis (EFA)

\begin{tabular}{|c|c|c|c|c|c|}
\hline \multicolumn{6}{|c|}{ Factor Loadings } \\
\hline Items & $\begin{array}{l}\text { Information } \\
\text { Quality }\end{array}$ & $\begin{array}{l}\text { System } \\
\text { Quality }\end{array}$ & $\begin{array}{l}\text { Service } \\
\text { Quality }\end{array}$ & $\begin{array}{l}\text { E- } \\
\text { Satisfaction }\end{array}$ & E-Loyalty \\
\hline IQ1 & 0.785 & & & & \\
\hline IQ2 & 0.700 & & & & \\
\hline IQ3 & 0.657 & & & & \\
\hline IQ4 & 0.626 & & & & \\
\hline IQ5 & 0.538 & & & & \\
\hline SQ1 & & 0.779 & & & \\
\hline SQ2 & & 0.721 & & & \\
\hline SQ3 & & 0.663 & & & \\
\hline SQ4 & & 0.642 & & & \\
\hline SQ5 & & 0.588 & & & \\
\hline SQ6 & & 0.467 & & & \\
\hline SRQ1 & & & 0.974 & & \\
\hline SRQ2 & & & 0.892 & & \\
\hline SRQ3 & & & 0.889 & & \\
\hline SRQ4 & & & 0.826 & & \\
\hline SRQ5 & & & 0.795 & & \\
\hline SRQ6 & & & 0.648 & & \\
\hline
\end{tabular}




\begin{tabular}{lcc}
\hline SAT1 & 0.871 & \\
SAT2 & 0.801 & \\
SAT3 & 0.786 & \\
LOY1 & & 0.832 \\
LOY2 & & 0.813 \\
LOY3 & & 0.799 \\
LOY4 & & 0.792 \\
LOY5 & & 0.627 \\
\hline
\end{tabular}

Extraction Method: Maximum Likelihood. Rotation Method: Promax with Kaiser Normalization. a. Rotation converged in 7 iterations. (IQ: information Quality, SQ: system quality, SRQ: service quality, SAT: satisfaction, LOY: e-loyalty)

The internal consistency reliability of all items was examined by Cronbach alpha, and item to total correlations. Therefore, the alpha coefficients, and item to total correlations for each construct are shown in Table 3. The Cronbach's alpha of all measurement constructs ranges from 0.880 to 0.949 . Normally the minimum value of Cronbach's alpha is 0.7 has considered as a cut off for reliability $[75,76]$.

Convergent validity of measures has been examined based on items standardized factor loadings, composite reliability, and the average variance extracted. The results of the convergent validity tests are also presented in Table 3. Standardized factor loadings of all items in each construct a range for information quality (0.844-0.929), system quality (0.669-0.824), service quality (0.820-0.899), e-satisfaction (0.847-0.871) and e-loyalty (0.682-0.835), these values show the better agreement because the minimum recommended level is 0.60 [74]. The composite reliabilities (CR) range from 0.949 (information quality) to 0.873 (e-loyalty), however their minimum recommended level is 0.70 . The average variance extracted (AVE) measures range from 0.550 (system quality) to 0.790 (information quality) and their minimum recommended threshold level is 0.5 [74]. So we measured the value of AVE, CR and factor loadings are in the range of convergent validity of the measurement items.

Table 3. Results of Internal Reliability and Convergent Validity Tests

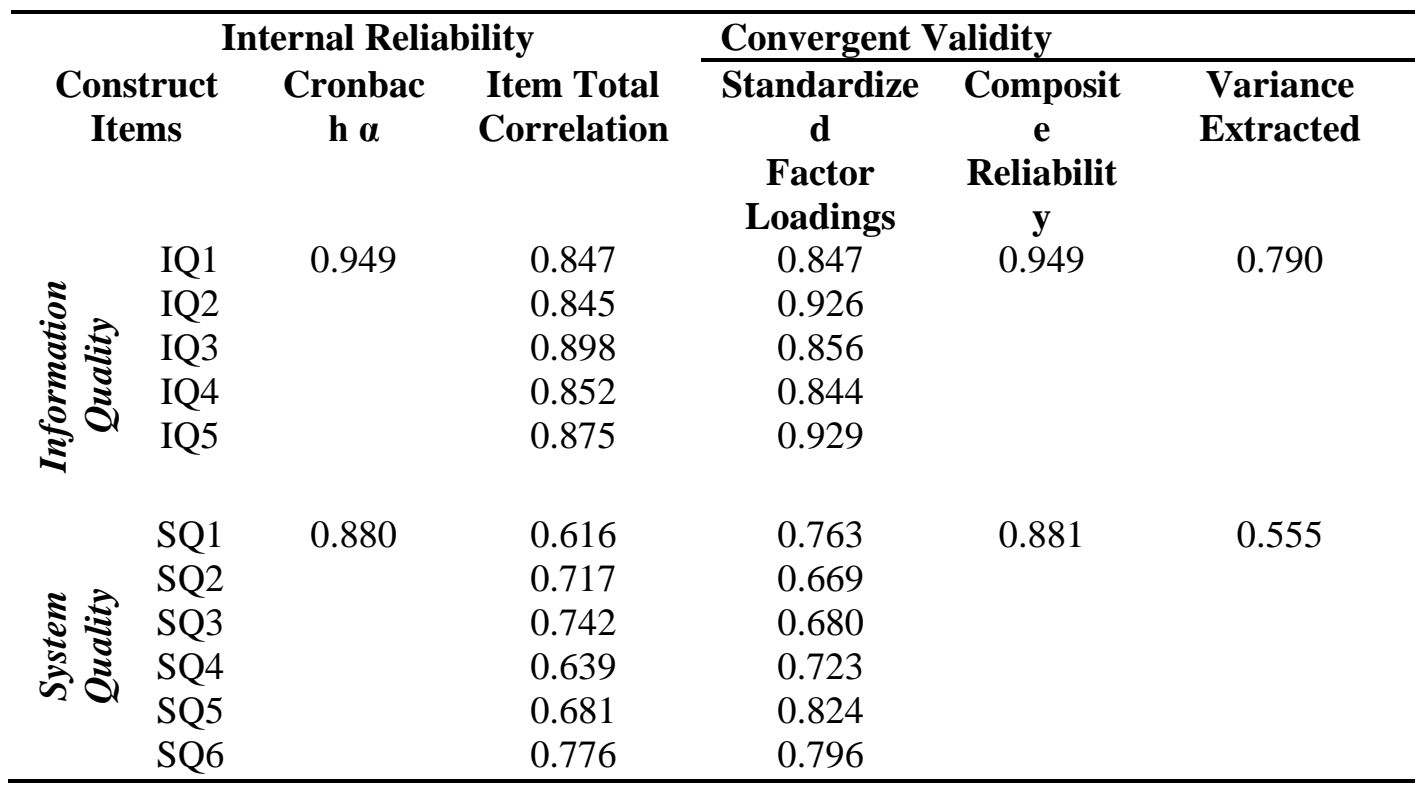




\begin{tabular}{|c|c|c|c|c|c|c|}
\hline \multirow{6}{*}{ 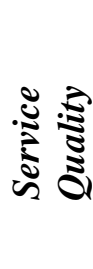 } & SRQ1 & 0.944 & 0.807 & 0.899 & 0.945 & 0.741 \\
\hline & SRQ2 & & 0.793 & 0.848 & & \\
\hline & SRQ3 & & 0.862 & 0.899 & & \\
\hline & SRQ4 & & 0.872 & 0.846 & & \\
\hline & SRQ5 & & 0.835 & 0.820 & & \\
\hline & SRQ6 & & 0.831 & 0.850 & & \\
\hline \multirow{3}{*}{ : } & SAT1 & 0.894 & 0.793 & 0.864 & 0.896 & 0.741 \\
\hline & SAT2 & & 0.805 & 0.871 & & \\
\hline & SAT3 & & 0.784 & 0.847 & & \\
\hline \multirow{5}{*}{ 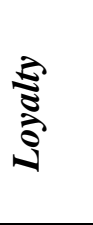 } & LOY1 & 0.881 & 0.682 & 0.832 & 0.873 & 0.580 \\
\hline & LOY2 & & 0.745 & 0.835 & & \\
\hline & LOY3 & & 0.746 & 0.682 & & \\
\hline & LOY4 & & 0.779 & 0.733 & & \\
\hline & LOY5 & & 0.636 & 0.712 & & \\
\hline
\end{tabular}

\section{Analysis and Results}

We used AMOS (IBM Version-21) to analyze the data and demonstrate structural equation modelling (SEM) which is a powerful multivariate analysis technique used to measure latent variables and investigate the causal relationship among variables. Particularly, SEM allows conducting confirmatory factor analysis (CFA) for theory development and testing. It is helpful and deemed a suitable tool to test the hypotheses in this study. The overall model fit indices are $\mathrm{x}^{2}=599.49, \mathrm{df}=262$ ( $\mathrm{p}$-values $=0.00$ ), GFI $=0.90$, AGFI $=0.87, \mathrm{NFI}=0.94, \mathrm{CFI}=0.96$, RMSEA $=0.05$ indicating that model is acceptable with no substantive differences. The fit indices of structural model are presented in Table 4 . The path between system quality and e-satisfaction $(\beta=0.27)$, service quality and e-satisfaction $(\beta=0.34)$, information quality and e-satisfaction $(\beta=0.31)$, esatisfaction and e-loyalty $(\beta=0.55)$, are found significant and support $\mathrm{H} 1, \mathrm{H} 2, \mathrm{H} 3$, and H6 respectively. This study also investigates the influence of information quality in the context of system quality $(\beta=0.56)$ and service quality $(\beta=0.76)$ is also found positive significant and support H4, H5 respectively. In this way information quality has a direct positive significant influence on e-satisfaction and impact indirectly via system and service quality. This evidence shows that e-tailers should design effective mechanism of information management to improve the website contents, service structure, process innovations and integration to develop sustainable relationship with customers.

This study verified that e-satisfaction is a direct antecedent of e-loyalty in the context of a young generation of Chinese e-tailing. The results are consistent with the previous literature, which prove that higher level of customer satisfaction will lead to greater customer loyalty $[77,78]$. The standardized parameter estimates of hypothesized paths are presented in Table 5 and structural equation modelling of framework depicted in Fig.2.

Table 4. Fit Indices of Model

\begin{tabular}{lll}
\hline Fit Index & Scores & $\begin{array}{l}\text { Recommended cut-off } \\
\text { values }\end{array}$ \\
\hline Absolute fit Measures & & The lower, the better \\
$\begin{array}{l}\text { Minimum fit function chi-square } \\
\left(\mathrm{x}^{2}\right)\end{array}$ & $599.49(\mathrm{p}=0.00)$ & \\
Degree of freedom (d.f) & 262 & $<5$ \\
$\left(\mathrm{x}^{2}\right) /$ d.f & 2.288 & $>0.80$ \\
Goodness-of-fit index (GFI) & 0.90 & $<0.05$ \\
Root mean square residual (RMSR) & 0.05 & \\
\hline
\end{tabular}




\begin{tabular}{lll}
\hline Incremental fit measures & & $>0.80$ \\
Adjusted goodness-of-fit index & 0.87 & $>0.90$ \\
(AGFI) & 0.96 & $>0.90$ \\
Tucker-Lewis index (TLI) & 0.94 & $>0.90$ \\
Normal fit index (NFI) & 0.96 & \\
$\begin{array}{l}\text { Comparative fit index (CFI) } \\
\text { Parsimonious fit measures }\end{array}$ & \\
$\begin{array}{l}\text { Parsimonious normed fit index } \\
\text { (PNFI) }\end{array}$ & 0.82 & The higher, the better \\
$\begin{array}{l}\text { Parsimonious goodness-of-fit index } \\
\text { (PGFI) }\end{array}$ & 0.72 & The higher, the better \\
\hline
\end{tabular}

Table 5. Standardized Parameter Estimates of Hypothesized Paths

\begin{tabular}{lccc}
\hline Hypotheses & Path & $\begin{array}{c}\text { Coefficient } \\
\text { (t-value) }\end{array}$ & Result \\
\hline The influence of e-tail online quality dimensions on e-satisfaction & \\
H1 & System quality $\rightarrow$ e-satisfaction & $0.27(3.1)$ & Supported \\
H2 & Service quality $\rightarrow$ e-satisfaction & $0.34(5.7)$ & Supported \\
H3 & information quality $\rightarrow$ e-satisfaction & $0.31(4.4)$ & Supported \\
H4 & Information Quality $\rightarrow$ system quality & $0.54(14.6)$ & Supported \\
H5 & Information Quality $\rightarrow$ service quality & $0.76(22.8)$ & Supported \\
The relationship between e-loyalty and e-satisfaction & & \\
H6 & E-satisfaction $\rightarrow$ e-loyalty & $0.55(8.6)$ & Supported \\
\hline
\end{tabular}

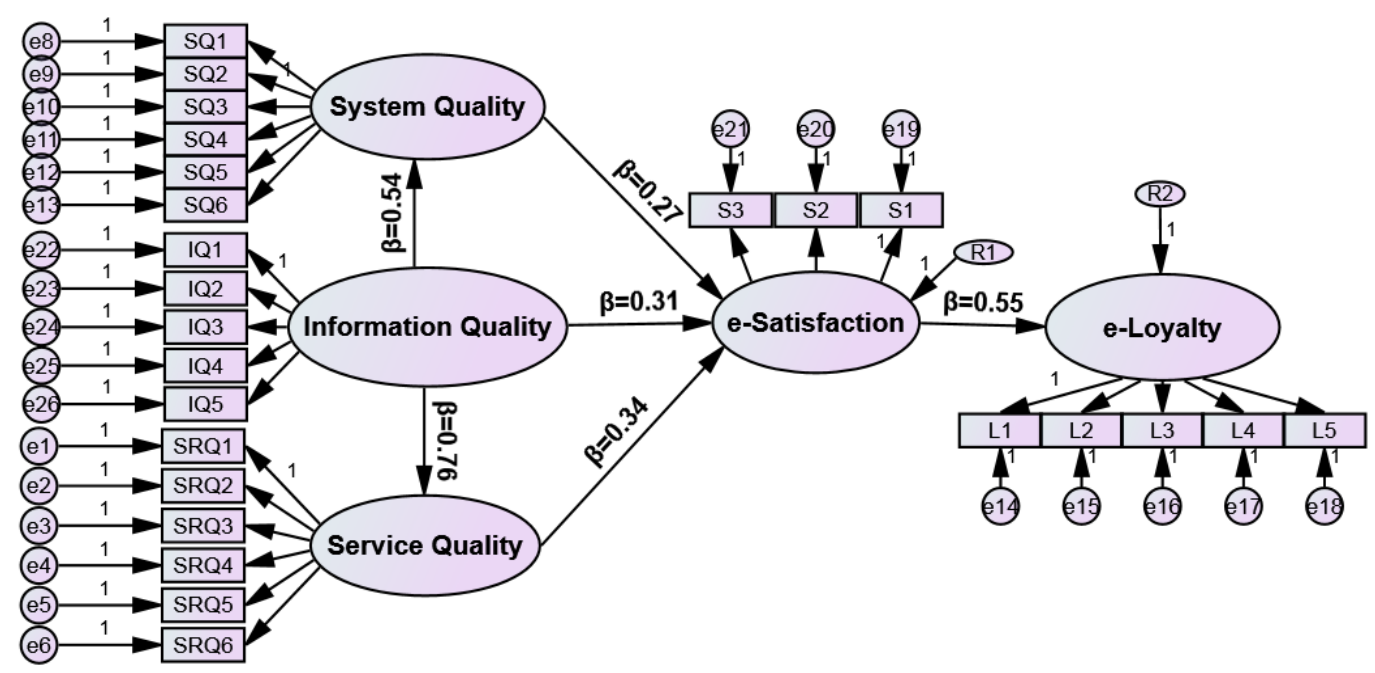

Figure 2. Results of the Structural Equation Model

Reichheld et al. [21] demonstrated that e-loyalty brings high rate of customer retention and reduced cost of customer acquisition, which leads to long term profitability to the etailer. The purpose of this study is to test a proposed integrative model of e-tail online quality dimensions, which effect on e-satisfaction and e-loyalty. The results indicate that e-satisfaction has a significant influence on e-loyalty. The results suggest that three online e-tail quality dimensions have different significant effects on e-satisfaction. Particularly system quality is the strongest predictor of e-satisfaction. In online retailing context, consumers prefer e-tailer website is designed according to their nature of desired products. In fact, consumers are very cautious to save their time in searching products from the website. Thus, ultimately they like such kind of websites having easy and quick navigation 
ability to search information along with the capacity of fast response about transaction processing. Particularly positive evaluation on the retailer's website design increases the consumer level of e-satisfaction. It is suggested that well designed and functional user interface system lead to a higher level of e-satisfaction. All dimensions of information quality (accurate, complete, reliable and timeliness information) contribute to influence on e-satisfaction significantly. Moreover the information quality also improves the system quality and service quality of e-tailing positively. Specifically, information quality has direct influence on e-satisfaction and indirectly it impacts via system quality and service quality. The characteristic of service quality like responsiveness, reliability, empathy, confidence and follow up services by e-tailers have a positive significant effect on esatisfaction.

\section{Discussion and Implications}

We explore the impact of online quality dimensions for a segment of students' e-tailing on e-satisfaction and loyalty. We used online quality dimensions as antecedents of esatisfaction which differentiates our study from previous research. Furthermore, this study highlights that three online quality dimensions examined directly contribute to the prediction of e-satisfaction, and indirectly to e-loyalty. System quality is a significant antecedent of e-satisfaction, this indicates that e-tailer website system oriented elements, such as website design, navigation, response time, security, access and functionality are the primary factors in measuring online customer perceptions of website performance. The website design and its easy access are important features of system quality that affects online customer satisfaction. Our results are consistent with the previous research by Lin [41], where website design is the fundamental determinants of customer satisfaction and also online presence increases e-satisfaction. Moreover, the online transaction security is the main features that affect e-satisfaction. Our results supports to the findings of Vijayasarathy [55] which identified transaction security has significant influence on the customer's attitude toward online shopping [55].

Furthermore, the case study about e-tailer system quality is demonstrated by Amazon in Wall Street, this case, providing the best customer web experience from the consumer's perspective.

Customer satisfaction scores are calculated based on price, merchandise and e-tailers online characteristics such as web contents and functionality. Amazon is the winner with satisfaction score, thus Amazon is a perfect example and is setting a new benchmarking for an excellent online customer experience [79].

Consistent with the hypotheses, e-tailers information quality elements can lead the customers to gain more e-satisfaction. The high information quality suited to customer's need and to reduce costs of information searching and processing. Similarly, information quality is associated with the system and service quality of e-tailers. This statement implies that e-tailers should provide accurate, current, useful, and complete information on their websites to satisfy the customer's needs. Services quality of e-tailers is the strongest determinant of customer's satisfaction. This is consistent with the result in Kim et al. [7], who found that reliability is the strongest predictor of e-satisfaction.

However, the results of this study show that e-satisfaction is positively related to eloyalty, and are consistent with the previous research [57, 80]. Lin and Sun [81] found that technology acceptance factor and website service quality impact e-loyalty. Substantially, researchers agreed that e-satisfaction is the primary predictor of e-loyalty [64, 82], but the strength of the relationship varies between satisfaction and loyalty [57]. Previously, Balabanis et al. [83] have examined e-satisfaction and e-loyalty in the context of standardized functional products (i.e. books and CDs), whereas, Christodoulides and 
Michaelidou [80] have investigated their relationship in the hedonic product categories like fashion accessories.

Usually there is no any face to face interaction between customers and e-tailers, to overcome this deficiency it is necessary for the e-tailers to assure their delivered products according to the expectation of the customers. Mc Knight et al. [84] suggested to improve the service quality of e-tailing according to customer's needs. E-tailers should strengthen consumer's beliefs such as competence and integrity, and to overcome the negative perceptions regarding uncertainty. Customers' superior perceptions of the services and convenience offered by retailers can improve the satisfaction [85]. Ou et al. [86] indicated that there has a positive relationship exists between service quality, relationship quality and loyalty.

Lin [41] demonstrated that responsiveness has a little positive effect on e-satisfaction. Subsequently, the Ali Baba case is the best example; as Kinnov (boutique software and web development firm in Asia Pacific) has developed a freshly designed customer loyalty website for Ali Baba. The site is built to maintain interaction with customers consistent with the Ali Baba brand [87].

This implies that e-tailers should improve their online quality dimensions consistently to induce e-satisfaction and e-loyalty. This study provides empirical evidence that system quality, service quality and information quality can influence e-loyalty through online customers' satisfaction. Online retailing managers should pay close attention to the development and changes in the online customer loyalty. Online customer loyalty should develop if the formation of e-tail quality dimensions, e-satisfaction is appropriately managed. Thus, e-tailing management attention might more fruitfully focus on the development of e-tailing quality dimensions. The e-tailer should focus on all quality dimensions simultaneously. System quality and information quality dimensions are easy to imitate. But the service quality is difficult to imitate, therefore e-tailers put more concentration to develop this dimension to accomplish competitive advantage. Moreover, this study encourages e-tailers to include measures of system quality, service quality and information quality, satisfaction and online customer loyalty into their present measurements of e-tailing. The e-tailing evaluation strategies should incorporate the direct and indirect effects of e-tailing quality dimensions, on e-satisfaction and loyalty.

In summary, it is important for e-tailers to realize the interrelationship among etail online quality dimensions, e-satisfaction and online customer loyalty. The online customers interact with e-tailers. They perceive that, they are interacting through a technical interface with the firm, and then they do not only evaluate e-tailers website performance but also considers their information quality and service quality of online retailing. Therefore, our results can help e-tailers who realize the role of e-tail online quality dimensions in building e-satisfaction and e-loyalty.

This study has managerial implications and suggestions. E-satisfaction is crucial for eloyalty, already known from previous research [57, 80]. Empirical evidence on how it can be built into the online shopping environment, however, loyalty has been largely an open phenomenon. This study sheds light on this issue that online quality dimensions as antecedents of e-satisfaction which play a central role in online shopping as well as that are under the control of e-tailers. Since system, information and service quality have both direct effects on e-satisfaction and indirect effect on e-loyalty. At first, in online shopping there is no any face to face contact, e-tailers design websites based on customers need. System quality can be achieved through improving e-tailer website design, an easy navigation of information, response time, security, availability and web functionality.

Second, e-tailers have to provide adequate and accurate information of online transactions to customers by using tactics such as search engine, information agent and information customization software to avoid information overload. Information quality can 
be achieved, to provide complete, accurate, timely and reliable information by e-tailers to their customers on websites.

Third, e-tailers need to adopt a customer oriented strategy and establish service oriented mechanism for transaction processes and provide effective resolution of customer related issues. Online service quality can be accomplished through e-tailer website design which anticipates and responds the users' requests promptly.

An e-tailer website would be able to stimulate consumers' confidence and to provide follow up services with desirable competency. Therefore, e-tailing online quality dimensions are building blocks of e-satisfaction, which turn to e-loyalty. Moreover, online companies should enhance e-tailing online quality dimensions and evaluate ongoing attempts by using the concept of e-satisfaction in the pursuit of customer e-loyalty. E-tail online quality dimensions find the positive influence e-satisfaction.

This shows that the online companies should be more considerate of the role of these dimensions to improve the consumer experience and facilitate them by making online shopping more efficient and easier. Despite the fact that the information quality was found to be an important antecedent of e-satisfaction, and significant relationship between system and service quality demonstrates to directly increase e-satisfaction and indirectly eloyalty. Our study provides guideline to managers regarding how to invest time and other resources in the context of e-tailing competitive area.

Our results play a vital role for such firms that are using e-commerce applications in China. These results are helpful for Chinese firms' managers that how to improve the key areas of e-tailing applications, e-satisfaction and e-loyalty. Managers of e-tailing websites can also improve online quality dimensions by establishing and sustaining a good reputation. The practitioners can use our results as guidelines in website development, daily operation and customer services and support in online retailing.

\section{Conclusions and Future Research Directions}

This study has greater comprehensiveness and richness of the online retailing literature and enhances our understanding of the impact of e-tail quality dimensions on e-loyalty. This study extends the e-tailing literature by indicating the online quality dimension practices in China.

It is clear that online business competition is diverse, and it has created a lot of opportunities for consumers to buy the right products from the market space. Substantially, it is imperative that internet endeavors would be executed very carefully with the ultimate goal of building customer relationship. As marketing on the internet is quite new and very challenging to attract and retain customers. Therefore, in this study, we demonstrated a framework for building loyalty based on e-tail online dimensions in the context of ecommerce. We found integrative constructs as determinants to customer's satisfaction: system, service and information quality. Thus, firms can address these three dimensions via website design, process integration, and content management. Therefore, high levels of system, service, and information quality dimensions are prerequisites for successful etailing and, inducing the customers to revisit their website. Furthermore, it is suggested that efficient and effective management information system designed can substantially contribute to more strengthening their e-tail online dimensions.

This study encompasses some limitations. First, the large share of the samples consists of students which may not be truly representative of the general population of the online shopping in China. Second, this study does not distinguish various product categories in testing the integrative model of e-loyalty. Third, our study omits the effect of specific brands on e-loyalty. Lie et al. (2000) found that brand can relieve perceived risks to a large extent and have a reassuring effect on customers. Finally, generalization results of our study are limited to the context of e-tailing in China, because all of the observations in our 
study are taken from China. So e-tailing in other countries may not resemble with China. Our study creates a paradigm for future studies and research and also carried out to investigate the role of e-tail quality dimensions of the specific products or different brand categories.

\section{Acknowledgements}

The authors wish to thank the anonymous referees for their valuable suggestions. This research was partly supported by the National Natural Science Foundation of China (Nos.71432003, 71271044).

\section{References}

[1] "China Internet Network Information Center-CINIC", Internet Development Shifted from "Quantitative Change" to "Qualitative Change" Mobile Phone Terminal Applications on the Rise online: http://www1.cnnic.cn/AU/MediaC/rdxw/hotnews/201401/t20140117_43849.htm, (2014).

[2] J. Meng, "Alibaba files for \$ 1 billion IPO in US Chain Daily", (2014).

[3] iResearch Inc. Reviews on China E-commerce Industry, available at: http://www.iresearchchina.com/views/5378.html, (2014).

[4] “An E-retailing research report commissioned by Goodman Group", Goodman Report , available at: http://article.wn.com/view/2012/05/22/Goodman_Report_Sees_Significant_Logistics_Opportunity_from t_al, (2014).

[5] CNNIC, "CNNIC statistic report of the development of internet in China", available at: http://www.cnnic.net.cn, (2014).

[6] D. Ribbink, A. C. Van Riel, V. Liljander and S. Streukens, "Comfort your online customer: quality, trust and loyalty on the internet", Managing Service Quality, vol. 14, no. 6, (2004), pp. 446-456.

[7] J. Kim, B. Jin and J. L. Swinney, "The role of etail quality, e-satisfaction and e-trust in online loyalty development process", Journal of Retailing and Consumer Services", vol. 16, no. 4, (2009), pp. 239-247.

[8] N. Subramanian, A. Gunasekaran, J. Yu, J. Cheng and K. Ning, "Customer satisfaction and competitiveness in the Chinese E-retailing: Structural equation modeling (SEM) approach to identify the role of quality factors", Expert Systems with Applications, vol. 41, no. 1, (2014), pp. 69-80.

[9] D. Cyr, "Modeling web site design across cultures: relationships to trust, satisfaction, and eloyalty", Journal of Management Information Systems, vol. 24, no. 4, (2008), pp. 47-72.

[10] Z. Yang and R. T. Peterson, "Customer perceived value, satisfaction, and loyalty: the role of switching costs”, Psychology \& Marketing, vol. 21, no. 10, (2004), pp. 799-822.

[11] S. S. Srinivasan, R. Anderson and K. Ponnavolu, "Customer loyalty in e-commerce: an exploration of its antecedents and consequences", Journal of Retailing, vol. 78, no. 1, (2002), pp. 41-50.

[12] A. C. Van Riel, V. Liljander and P. Jurriens, "Exploring consumer evaluations of e-services: a portal site", International Journal of Service Industry Management, vol. 12, no. 4, (2001), pp. 359-377.

[13] C. H. Park and Y. G. Kim, "Identifying key factors affecting consumer purchase behavior in an online shopping context", International Journal of Retail \& Distribution Management, vol. 31, no. 1, (2003), pp. 16-29.

[14] R. B. Woodruff, "Customer value: the next source for competitive advantage", Journal of the Academy of Marketing Science, vol. 25, no. 2, (1997), pp. 139-153.

[15] R. T. Rust, K. N. Lemon and V. A. Zeithaml, "Driving customer equity: Linking customer lifetime value to strategic marketing decisions (No. 108)", Marketing Science Institute, (2001).

[16] F. P. Reichheld and W. E. Sasser, "Zero Defections: Quality Comes To Services", Harvard Business Review, vol. 68, no. 5, (1990), pp. 105-111.

[17] F. F. Reichheld, "Loyalty-based management”, Harvard Business Review, vol. 71, no. 2, (1992), pp. 64 73.

[18] V. Shankar, A. K. Smith and A. Rangaswamy, "Customer satisfaction and loyalty in online and offline environments", International Journal of Research in Marketing, vol. 20, no. 2, (2003), pp. 153-175.

[19] J. Strauss, A. El-Ansary and R. Frost, "E-Marketing", International Edition, Prentice Hall, (2006).

[20] A. S. Dick and K. Basu, "Customer loyalty: toward an integrated conceptual framework", Journal of the Academy of Marketing Science, vol. 22, no. 2, (1994), pp. 99-113.

[21] F. F. Reichheld and P. Schefter, "E-loyalty: your secret weapon on the web", Harvard Business Review, vol. 78, no. 4, (2000), pp. 105-113.

[22] R. L. Oliver, "Satisfaction: A behavioral perspective on the consumer", McGraw-Hill, (1997).

[23] M. E. Porter, "Strategy and the internet", Harvard Business Review, vol. 79, no. 3, (2001), pp. 63-78.

[24] T. Ahn, S. Ryu and I. Han, "The impact of the online and offline features on the user acceptance of Internet shopping malls", Electronic Commerce Research and Applications, vol. 3, no. 4, (2005), pp 405-420. 
[25] B. Ives, M. H. Olson and J. J. Baroudi, "The measurement of user information satisfaction", Communications of the ACM, vol. 26, no. 10, (1983), pp. 785-793.

[26] J. Chuan, L. Chuan and H. Lu, "Towards an understanding of the behavioural intention to use a web site", International Journal of Information Management, vol. 20, no. 3, (2000), pp. 197-208.

[27] C. Liu and K. P. Arnett, "Exploring the factors associated with Web site success in the context of electronic commerce", Information \& Management, vol. 38, no. 1, (2000), pp. 23-33.

[28] C. Ranganathan and S. Ganapathy, "Key dimensions of business-to-consumer web sites", Information \& Management, vol. 39, no. 6, (2002), pp. 457-465.

[29] A. M. Aladwani and P. C. Palvia, "Developing and validating an instrument for measuring userperceived web quality", Information \& Management, vol. 39, no. 6, (2002), pp. 467-476.

[30] T. Ahn, S. Ryu and I.Han, "The impact of Web quality and playfulness on user acceptance of online retailing”, Information \& Management, vol. 44, no. 3, (2007), pp. 263-275.

[31] L. F. Pitt, R. T. Watson and C. B. Kavan, "Service Quality: A Measure of Information Systems Effectiveness", MIS Quarterly, vol. 19, no. 2, (1995), pp.173-187.

[32] J. W. Palmer, "Web site usability, design, and performance metrics", Information Systems Research, vol. 13, no. 2, (2002), pp. 151-167.

[33] D. Selz and P. Schubert, "Web Assessment-Some evidence from successful interactive WWW applications", International Journal of Electronic Markets, vol. 7, no. 3, (1997), pp. 1-4.

[34] P. Bharati and A. Chaudhury, "An empirical investigation of decision-making satisfaction in web-based decision support systems", Decision Support Systems, vol. 37, no. 2, (2004), pp. 187-197.

[35] W. H. Delone, "The DeLone and McLean model of information systems success: a ten-year update”, Journal of Management Information Systems, vol. 19, no. 4, (2003), pp. 9-30.

[36] A. L. Lederer, D. J. Maupin, M. P. Sena and Y. Zhuang, "The technology acceptance model and the World Wide Web", Decision Support Systems, vol. 29, no. 3, (2000), pp. 269-282.

[37] Z. Liao and M. T. Cheung, "Internet-based e-shopping and consumer attitudes: an empirical study", Information \& Management, vol. 38, no. 5, (2001), pp. 299-306.

[38] B. Shankar, "Electronic commerce will be a big business", Telecommunications, vol. 30, no. 7, (1996), pp. 24.

[39] R. J. Anderson and S. J. Bezuidenhoudt, "On the reliability of electronic payment systems", Software Engineering, IEEE Transactions, vol. 22, no. 5, (1996), pp. 294-301.

[40] C. Liu, K. P. Arnett and C. Litecky, "Design quality of websites for electronic commerce: Fortune 1000 webmasters' evaluations", Electronic Markets, vol. 10, no. 2, (2000), pp. 120-129.

[41] H. F. Lin, "The impact of website quality dimensions on customer satisfaction in the B2C e-commerce context", Total Quality Management and Business Excellence, vol. 18, no. 4, (2007), pp. 363-378.

[42] A. Bhattacherjee, "An empirical analysis of the antecedents of electronic commerce service continuance", Decision Support Systems, vol. 32, no. 2, (2001), pp. 201-214.

[43] J. Santos, "E-service quality: a model of virtual service quality dimensions", Managing Service Quality, vol. 13, no. 3, (2003), pp. 233-246.

[44] V. A. Zeithaml, "Service quality, profitability, and the economic worth of customers: what we know and what we need to learn", Journal of the Academy of Marketing Science, vol. 28, no. 1, (2000), pp. 67-85.

[45] S. J. Barnes and R. Vidgen, "An evaluation of cyber-bookshops: the WebQual method", International Journal of Electronic Commerce, vol. 6, no. 1, (2001), pp. 11-30.

[46] P. M. Doney and J. P. Cannon, "An examination of the nature of trust in buyer-seller relationships", The Journal of Marketing, vol. 61, (1997), pp. 35-51.

[47] J. J. Cronin Jr and S. A. Taylor, "Measuring service quality: a reexamination and extension", The Journal of Marketing, vol. 56, no. 3, (1992), pp. 55-68.

[48] E. W. Anderson, C. Fornell and D. Lehmann, "Customer satisfaction, market share, and profitability: findings from Sweden", The Journal of Marketing, vol. 58, no. 3, (1994), pp. 53-66.

[49] R. T. Rust and A. J. Zahorik, "Customer satisfaction, customer retention, and market share", Journal of Retailing, vol. 69, no. 2, (1993), pp. 193-215.

[50] M. Cameran, P. Moizer and A. Pettinicchio, "Customer satisfaction, corporate image, and service quality in professional services", The Service Industries Journal, vol. 30, no. 3, (2010), pp. 421-35.

[51] W. H. De Lone and E. R. McLean, "Information systems success: the quest for the dependent variable", Information Systems Research, vol. 3, no. 1, (1992), pp. 60-95.

[52] V. A. Zeithaml, A. Parasuraman and A. Malhotra, "Service quality delivery through web sites: a critical review of extant knowledge", Journal of the Academy of Marketing Science, vol. 30, no. 4, (2002), pp. 362-375.

[53] C. Flavián, M. Guinalíu and R. Gurrea, "The role played by perceived usability, satisfaction and consumer trust on website loyalty", Information \& Management, vol. 43, no. 1, (2006),pp. 1-14.

[54] S. Janda, P. J. Trocchia and K. P. Gwinner, "Consumer perceptions of Internet retail service quality", International Journal of Service Industry Management, vol. 13, no. 5, (2002), pp. 412-431.

[55] L. R. Vijayasarathy, "Predicting consumer intentions to use on-line shopping: the case for an augmented technology acceptance model", Information \& Management, vol. 41, no. 6, (2004), pp. 747-762.

[56] S. Y. Kim and Y. J. Lim, "Consumers' perceived importance of and satisfaction with internet shopping”, Electronic Markets, vol. 11, no. 3, (2001), pp. 148-154. 
[57] R. E. Anderson and S. S. Srinivasan, "E-satisfaction and e-loyalty: A contingency framework", Psychology \& Marketing, vol. 20, no. 2, (2003), pp. 123-138.

[58] R. S. Winer, "A framework for customer relationship management", California Management Review, vol. 43, no. 4, (2001), pp. 89-105

[59] S. Ram and H. S. Jung, "How product usage influences consumer satisfaction", Marketing Letters, vol. 2, no. 4, (1991), pp. 403-411.

[60] V. A. Zeithaml, L. L. Berry and A. Parasuraman, "The behavioral consequences of service quality", Journal of Marketing, vol. 60, no. 2, (1996), pp. 31-46

[61] D. M. Szymanski and R. T. Hise, "E-satisfaction: an initial examination”, Journal of Retailing, vol. 76, no. 3, (2000), pp. 309-322.

[62] J. Bloemer and K. De Ruyter, "On the relationship between store image, store satisfaction and store loyalty", European Journal of Marketing, vol. 32, no. 5-6, (1998), pp. 499-513.

[63] L. L. Berry, "Relationship marketing. American Marketing Association", Chicago, (1983)

[64] ForeSee, "Top 100 online retail satisfaction index", FGI Research, Am Arbor, MI, (2008).

[65] J. S. Chiou, "The antecedents of consumers' loyalty toward Internet service providers", Information \& Management, vol. 41, no. 6, (2004), pp. 685-695.

[66] A. Finn, L. Wang and T. Frank, "Attribute perceptions, customer satisfaction and intention to recommend e-services", Journal of Interactive Marketing, vol. 23, no. 3, (2009), pp. 209-220.

[67] S. Cai and Y. Xu, "Effects of outcome, process and shopping enjoyment on online consumer behavior", Electronic Commerce Research and Applications, vol. 5, no. 4, (2007), pp. 272-281.

[68] W. Rodgers, S. Negash and K. Suk, "The moderating effect of on-line experience on the antecedents and consequences of on-line satisfaction", Psychology \& Marketing, vol. 22, no. 4, (2005), pp. 313-331.

[69] C. Fornell, M. D. Johnson, E. W. Anderson, J. Cha and B. E. Bryant, "The American customer satisfaction index: Nature, purpose, and findings", Journal of Marketing, vol. 60, no. 4, (1996), pp. 7-18

[70] Fung Business Intelligence Center, Online retailing in China, available at: http://www.funggroup.com/eng/knowledge/research/china_dis_issue111.pdf, (2014).

[71] N. J. Lightner, M. M. Yenisey, A. A. Ozok and G. Salvendy, "Shopping behaviour and preferences in ecommerce of Turkish and American university students: implications from cross-cultural design”, Behaviour \& Information Technology, vol. 21, no. 6, (2002), pp. 373-385.

[72] C. Yoon, "The effects of national culture values on consumer acceptance of e-commerce: Online shoppers in China”, Information \& Management, vol. 46, no. 5, (2009), pp. 294-301.

[73] S. Bames and R. Vidgen, "An integrative approach to the assessment of ecommerce quality", Journal of Electronic Commerce Research, vol. 3, no. 3, (2002), pp. 114-127

[74] J. F. Hair, R. L. Tatham, R. E. Anderson and W. Black, "Multivariate data analysis", Prentice-Hall, (1998).

[75] J. C. Nunnally, "Psychometric Theory", McGraw-Hill, (1978).

[76] J. F. Hair, W. C. Black, B. J. Babin, R. E. Anderson and R. L. Tatham, "Multivariate Data Analysis", NJ: Pearson Prentice Hall, (2006).

[77] R. M .Morgan and S. D. Hunt, "The commitment-trust theory of relationship marketing", Journal of Marketing, vol. 58, no. 3, (1994), pp. 20-38.

[78] A. H. Zins, "Relative attitudes and commitment in customer loyalty models: some experiences in the commercial airline industry", International Journal of Service Industry Management, vol. 12, no. 3, (2001), pp. 269-294.

[79] ForeSee, The foresee experience index (FXI) U.S, Retail Edition, available at: http://www.foresee.com/research-white-papers/_downloads/foresee-experience-index-2013-us-retailedition.pdf, (2014).

[80] G. Christodoulides and N. Michaelidou, "Shopping motives as antecedents of e-satisfaction and eloyalty", Journal of Marketing Management, vol. 27, no.1-2, (2010), pp. 181-197.

[81] G. T. Lin and C. C. Sun, "Factors influencing satisfaction and loyalty in online shopping: an integrated model", Online Information Review, vol. 33, no. 3, (2009), pp. 458-475.

[82] H. Evanschitzky, G. R. Iyer, J. Hesse and D. Ahlert, "E-satisfaction: a re- examination", Journal of Retailing, vol. 80, no. 3, (2004), pp. 239-247.

[83] G. Balabanis, N. Reynolds and A. Simintiras, "Bases of e-store loyalty: Perceived switching barriers and satisfaction, Journal of Business Research, vol. 59, no. 2, (2006), pp. 214-224.

[84] D. H. McKnight, V. Choudhury and C. Kacmar, "The impact of initial consumer trust on intentions to transact with a web site: a trust building model”, The Journal of Strategic Information Systems, vol. 11, no. 3, (2002), pp. 297-323.

[85] M. P. M. Ruiz, A. I. J. Zarco and R. Cascio, "Assessing the maximum level of customer satisfaction in grocery stores: a comparison between Spain and the USA", International Journal of Retail \& Distribution Management, vol. 39, no.7, (2011). pp. 504-521.

[86] W. M. Ou, C. M. Shih, C. Y. Chen and K. C. Wang, "Relationships among customer loyalty programs, service quality, relationship quality and loyalty: An empirical study", Chinese Management Studies, vol.5, no. 2, (2011), pp. 194-206.

[87] Kinnov, Ali Baba the ultimate kebab, available at: http://www.kinnov.com/case-studies/alibaba (2014).

[88] J. Meng, "Wholesale city riding wave of e-commerce", Chain Daily, (2014). 